\title{
A Viewpoint on the Italian Diplomacy Towards the Albanian Monarchy (1928-1939)
}

\author{
Dr. Esilda Luku \\ Faculty of Political Sciences and Law \\ University "Aleksandër Moisiu", Durrës, Albania \\ esildaluku@yahoo.com
}

\section{Doi:10.5901/mjss.2013.v4n11p258}

\section{Abstract}

This paper aims to analyze the diplomacy of Italy based on its economic and political interests during the monarchical system of governing in Albania. The Italian government strongly supported the intention of Ahmet Zogu to transition from Presidential Republic to Monarchy, in order to ensure the domestic political stability and the reduction of the continuous confrontations caused by neighbors' intrigues. It approved the proclamation of Zogu as "King of Albanians", who would strengthen the bilateral relations and attend a common policy in accordance with the Treaty of the Defensive Alliance, signed on November 22, 1927. The Italian government competed with Yugoslavia to control the Adriatic Sea and to establish the economic hegemony in Albania and elsewhere in the Balkans. Rome used the difficult economic and financial situation of Albania in the circumstances of the Great Depression to provide a loan of 100 million gold francs for ten years without interest. But, it was cancelled due to non-renewal by the Albanian government of the Friendship and Security Pact with Italy in November 1931. Thus, Italy demanded the repayment of the loan provided by SVEA (Società per lo Sviluppo Economico dell'Albania) and customs union with Albania, which were rejected by King Zogu I because its country was turned simply into an Italian colony. The signing of a series of bilateral economic agreements not only extended the Italian control in Albania, but also contributed to the development of the Albanian economy during the monarchy. Moreover, Italy with the support of Britain aimed at strengthening the political domination in the Balkans against the Franco-Yugoslav alliance that organized the Balkan Conferences (1930-1934). It opposed King Zogu I efforts for an independent foreign policy and put under pressure the Balkan countries not to accept Albania in the Balkan Pact signed on February 9, 1934. The Italian diplomacy intended to establish a protectorate in Albania and Count Ciano sent King Zogu I successive proposals that included: 1) the control of the means of communication in the case of threat to the independence of the Albania; 2) an Italian consultant in each ministry; 3) the recognition of civil and political rights for the Italians living in Albania and 4) the respective legacies turned into embassies. King Zogu I refused such an agreement because it violated the independence and the territorial integrity of Albania. He alerted the Great Powers to the Italian threat, but faced with the Western indifference. On April 7, 1939, Italy invaded Albania in violation of the deal with Britain to maintain the status quo in the Mediterranean.

Keywords: Italian diplomacy, economic interests, political influence, Albanian Monarchy.

\section{Introduction}

The opinion of Great Powers was essential to fulfilling the ambition of President Zogu aimed at changing the form of governing from Presidential Republic to a Monarchy. For that reason, he appointed the Minister of Foreign Affairs, Hysen Vrioni, to secure the consent of the European chancelleries, including Italy, which strongly lobbied internationally for the civilizing role to be played by the Albanian Monarchy. The Italian Minister in Albania, Ugo Sola, advised Zogu to follow certain legal procedures to legitimate the constitutional change of the system of governing. Thus, on September 1, 1928, based on Article 1 of the Fundamental Statute, the Constitutional Assembly declared Albania a "Democratic, Parliamentary and Hereditary Monarchy" with Ahmet Zogu - "King of Albanians" named Zogu I (Laporte, 1936, p. 3).

The Albanian Monarchy had several advantages compared to the republican system of governing. At first, it coincided with the historical tradition of the Albanians to show loyalty to a prince (Gogo, 1938, p. 43). Secondly, a consolidated and a hereditary monarchy would avoid rivalries between politicians during the presidential elections. Thirdly, the monarchy would prevent the continuous conflicts from the neighboring countries. The experiences in United Kingdom, Italy, Yugoslavia and Greece, had shown that such regimes felt less threatened by foreign intrigues than presidencies with limited mandates. At last, the King of Albanians, considered as one of the most famous political and military leaders, could solve the difficult problems of his country (Grant, 2002, p. 20).

The Italian diplomacy was the first to officially recognize the Albanian Monarchy and sent the congratulations to Zogu I. Rome guaranteed to respect the reciprocal interests and to cooperate with the Albanian government on all issues related to the situation in the Balkans (Swire, 2005, p. 408). 


\section{Italian economic expansion in Albania}

The Adriatic rivals, Italy and Yugoslavia, competed to increase the influence on the Albanian economy. The newspaper of Beograd "Les Nouvelles Jougoslaves" appealed to Albania to better accept cooperation with its neighbors rather than an interested protection outside the Balkans. The Albanian government had signed with Italy an alliance based on reciprocal interests and with Yugoslavia several treaties that facilitated the economic relations between the two countries. Both Rome and Beograd followed the policy of economic hegemony in the Adriatic Basin. In order to maintain the economic independence, Albania could benefit from Italy becoming a transit country to bring its industrial products in the general Balkan market, while from Yugoslavia the use of our ports than that of Thessaloniki (Canco, 1929, p. 2).

The Great Depression (1929-1933) hit the Albanian economy, too, that was reflected in the decline of the agricultural and industrial production, increased unemployment, rising inflation, passive trade balance etc. The collapse of the economy forced King Zogu I to accept another Italian loan. Though he knew the potential risk due to the Italian financial assistance, but he had no other alternative. On June 24, 1931, the representatives of the Albanian and the Italian government signed a new financial agreement ("What is the base of ..., 1931, p. 1). Referring to its content: 1) Italy would give the Albanian state a loan of 10 million gold francs per year, without interest, for e period of 10 years, for economic and cultural purposes, as well as to cover the budget deficit, recognizing at the same time that the amount of annual payments above would be reduced in proportion to the extent of the national income growth or by reducing the expenses, which could result in the financial situation of Albania. 2) The loan would not be paid unless the Albanian annual income amounted to 50 million gold francs. 3) For the administration and the delivery of the money was charged a mixed commission, composed by 4 people, 2 Italians and 2 Albanians, who would be appointed by the Albanian government. The decisions of the commission would be taken by majority vote (Fischer, 2004b, p. 211).

But, the non-renewal of the First Pact of Tirana, in November 1931, tensioned the relations between Albania and Italy. The last one used the economic and financial difficulties of the government in Tirana to ask for the payment of SVEA's loan. King Zogu I complained to the British Minister that Rome had promised they would never pay the loan. The same thing was stated by Ugo Sola, who emphasized that the Italian government had no intentions to use the loan for its goals, but it would be subject of successive moratoria (Fischer, 2004b, p. 221).

Contrary to the statements, Rome changed the political course. It was obvious that the monarchy had no possibility to pay the loan, that's why Italy insisted on respecting the terms of the contract of SVEA with its shareholders. Because of the customs revenues were used to pay the debt, the Italian government proposed to Tirana the customs union, in December 1932. It consisted in the removal of custom duties on trade between the two countries, transforming Albania into a mere Italian colony (The Archive of Institute of History (AIH), A.V.60, p. 25). Such a proposal was not accepted by King Zogu I.

The Italian diplomacy continued putting pressure on the Albanian government canceling on April 1, 1933, the loan of 100 million gold francs, granted two years ago (AlH, A.V.43, p. 24). This fact obliged the King's counselor, Mehmet Konica, to make a request to Beograd for a loan of 3 million francs. According to the Yugoslavian Ambassador in Tirana, the loan was very important in order to avoid the anarchy or the capitulation before Italy. But, the Yugoslavian government lacked free funds aimed at helping the Albanian state (Smirnova, 2004, p. 179).

In these conditions, when no European country did support Albania financially, the Italian Ambassador in Tirana, Mario Indelli, and the Albanian Minister of Economy, Dhimiter Beratti, signed on March 19, 1936, six economic and financial agreements, as follows: 1) The cancellation of the 1931 loan through paying the backlog amounted to nearly 3 million gold francs. 2) A sum of 9 million gold francs would be granted to the Albanian government to cover last year budget deficit. 3) A grant of 10 million gold francs intended to develop the agriculture would be paid for 50 years at $1 \%$ interest guaranteed by the kerosene concession's obligations. 4) A loan of 3 million gold francs would be given for the creation of the State Tobacco Monopoly for 15 years without interest. 5) The agreement on the construction of the port of Durazzo and the loan contracted with a Credit Institute aimed to finish the installations of the scaffolding for trade purposes. 6) The cancellation for 5 years of the payments that the Albanian government owed to SVEA for 50 million loans (AlH, A.V.42, pp. 51-54).

The agreements above influenced positively on the formation of the necessary structures and the gradual improvement of the economic and financial situation in the country. In particular, the loan for the development of the agriculture was of great importance. Also, the Albanian government benefited from the amortization of SVEA's loan. While the loan of 50 million gold francs estimated at 65 after the increase in value of lira helped the construction of many public works in Albania, such as: 1000 minor and major bridges, road traffic, public buildings, the harbor of Durazzo etc. (Attoma, 1936, p. 1). 
In March 1938, Societa Italiana delle Miniere di Selenizza (SIMS-a) obtained the concession for iron exploitation in the prefecture of Lissus and, in the same month, the minister of Economy, Terenc Toci, signed with this society an agreement that gave the right to the Italian concessionaire "to explore, work, export and sell pyrite, copper and any other mineral or metal found in the area Mat - Rubik - Vela Church - Koter-Kryzi, for a period of 50 years". Another Italian company AMMI (Aziende Minerali Metallici Italiani) began the exploitation of chromium in Pogradec, Kukës and Tropojë (AlH, A.V.43, p. 26). In April 1938, the "Pescalba" company won the right of fishing in the waters of Albania for 300.000 gold francs per year and $5 \%$ of the profits for 25 years (AlH, A.V.42, p. 56).

The Italians won concessions in the financial field, too. The Statute of Napoli's Bank in Albania was approved in March 1938. At the same time, the "Agricultural Bank of the State" was founded. Although an Albanian credit institute, it was under the Bank of Napoli and ran by Italians (The History of the Albanian People, vol. 3, 2007, p. 349).

The foreign investments helped the economy growth and prosperity. The Italian company, AIPA (Azienda Italiana Petroli Albania), which used the kerosene especially in the area of Devoll (Kuçovë), had opened 445 pits that enabled the increase of kerosene production from 1000 tons in 1935 to 1500 tons every month, thus 200.000 tons per year ("Albanian properties of kerosene ..., 1939, p. 1). Other Italian enterprises, such as: SIMS-a, SAMIA, SESA etc. made also very important investments in Albania. Only in the oil factory in Valona, owned by Roberto Alegros, were invested 800.000 gold francs. In total, the foreign investments in industry accounted over 100 million gold francs, mainly Italian capital than French and German one (Kareco, 2010, p. 75).

The foreign economic domination, Italian particularly, caused no financial bankruptcy in the Albanian economy. Though the effects of the Great Depression were evident, the technological backwardness, the lack of domestic capital etc. again the investments and the economic development went on as conditions allow. So, the annual customs revenues recorded 6 million gold francs, the state monopoly on salt, paper cigarettes and matches up to 2.5 million gold francs, without mentioning the income tax etc. The bank deposits only, as an indicator of loan capital accumulation, grew relatively rapidly by $200 \%$, while the savings accounts increased by $750 \%$. Despite the problems and the difficulties, the Albanian economy was on the right track, as shown in the following table (Kareco, 2010, pp. 68-70).

Table 1: Financial indicators for the years 1928 and 1938

\begin{tabular}{|l|l|c|c|}
\hline \multicolumn{2}{|l|}{} & 1928 & 1938 \\
\hline 1. & The amount of currency in circulation, in gold francs & 10.095 .000 & 10.529 .000 \\
\hline 2. & Price index, in percentage & 100.000 & 65.86 \\
\hline 3. & Interest rate, in percentage & 9 & 6 \\
\hline 4. & Granted loans, in gold francs & 5.058 .000 & 8.199 .826 \\
\hline $\mathbf{5 .}$ & Bank deposits, in million gold francs & 5.526 .000 & 12.155 .000 \\
& Savings deposits, in gold francs & 221.000 & 1.652 .000 \\
\hline 6. & Treasure at the National Bank of Albania, on December 31, 1938, in gold francs & 32.400 .000 \\
\hline
\end{tabular}

\section{The policy of fascist Italy towards the Albanian Monarchy}

The Italian diplomacy aimed at increasing the political influence on Albania for further deportation in the East. There were signed many political and economic agreements between the two countries in order to enforce their cooperation. But, the possibility of non-renewal of the Friendship and Security Pact, on November, 1931, tensioned the bilateral relations. King Zogu I discussed the matter with the Minister of Economy, Mehdi Frashëri, and the Prime Minister, Pandeli Evangjeli, who criticized the non-reciprocal content of the pact which threatened the independence of Albania. According to them, 1) the pact recognized the Italian interests; 2) Rome was responsible for maintaining the political and juridical status quo of Albania and, 3) if necessary, the Italian government may send an army contingent to Albania (Frashëri, 2005, pp. 232233).

This political stance of the royal government dissatisfied Rome. Benito Mussolini charged General A. Pariani to convince King Zogu I for the renewal of the First Pact of Tirana, but the negotiations ended unsuccessfully. Although the Italian government was conscious that its position remained unchanged due to the guarantee of the Treaty of the Defensive Alliance, signed on November 22, 1927, for a period of 20 years. But, this political movement witnessed the efforts of King Zogu I to benefit as much as possible from Italy, without falling under its influence (AlH, A.V.16, p. 21).

In response, the Italian government asked for the payments of SVEA's loan and the customs union that were rejected by King Zogu. Based on the refusal of the Great Powers and the neighboring countries to support Albania financially, Rome sent an ultimatum to the monarchy, in August 1933, as follows: 1) the denouncement of all trade 
agreements made with other states and the new treaties would be signed with the consent of Italy; 2) Albanian officials, that did not have "an Italian culture", should be replaced with those who possessed this "culture" or Italians; 3) the military buildings of the country ought to be sold to the Italian Ministry of War; 4) the General Inspector of Gendarmerie, the British General Percy and his officers had to leave in order to be replaced by the Italian "instructors", who would be paid directly from Rome; 5) the opening of all Catholic schools that were closed recently from the Albanian government; 6) the Italian language to be compulsory in the secondary schools and the Albanian students would be invited to the Italian universities; 7) the French Lycée in Koritza should be replaced with an Italian one (Albanian's State Archive (AQSH), F. 263, V.1933, D. 25, pp. 13-14). These requirements were unacceptable for King Zogu I because they threatened the sovereignty and the independence of Albania.

The disagreements between the two countries culminated on June 22, 1934, when 20 warships anchored in the port of Durazzo without notifying the local authorities. It was an open demonstration of force by fascist Italy. King Zogu I informed immediately the diplomats of Britain and France in Albania, who demanded explanation from the Italian government. But, B. Mussolini played a double game. On one hand, he apologized for the delay of the note that announced the arrival of the battleships and, on the other hand, he issued an ultimatum demanding the return of the "military mission" headed by Pariani and asked King Zogu I for a solemn promise that Albania would not join the Balkan Entente (AlH, A.V.60, pp. 27-38).

On the contrary, the Albanian delegation participated in the Balkan Conferences which was considered by the Italian diplomacy as a manifestation of King Zogu I to pursue an independent foreign policy. Though the conferences had economic benefits, politically they operated to the detriment of the alliance with Italy. France and Yugoslavia cooperated to ruin the friendship of Rome with the other Balkan states. This policy was unreasonable for the Albanian government that, referring to the Treaty of Tirana, declared its readiness to leave the conference neither sign nor ratify any agreement with the neighbors that was against Italy ("The Balkan Conference", 1930, p. 2). Moreover, the head of the Albanian delegation, Mehmet Konica, insisted on the obligation of Greece and Yugoslavia to guarantee the respect of the Albanian minority rights (Meta, 2011, p. 52).

But, the Italian diplomacy exerted pressure on the participating states to refuse Albania in the Balkan Pact (AlH, A.V.85, pp. 3-4). On February 9, 1934, the foreign ministers of Greece, Turkey, Rumania and Yugoslavia signed the Balkan Pact at the Academy of Athens. France and Britain welcomed the agreement and expressed their regrets for the lack of Bulgaria and Albania as Balkan countries. While the neighbors deliberately didn't invite Albania to sign the Balkan Pact for several reasons: At first, the inability to cope with the pressure of fascist Italy. Secondly, the participation in the Balkan Entente paved the way for the Albanian government to cooperate with its neighbors to resolve the issue of minorities. Thirdly, the admission of Albania in the Balkan Pact meant a stabilized and a consolidated state that was not in conformity with the Greek and the Yugoslav intentions. The neighboring countries wanted a weak state with an ineffective government in order to justify their plans for the partition of Albania (Bakalli, 2001, pp. 67-70).

Furthermore, in August 1934, Baron Pompeo Aloisi made the following proposals to King Zogu I: 1) the two countries had to share the same foreign policy; 2) Italy should be given a naval base in Durazzo and an air one in Tirana. The fortifications would be under the Italian control. 3) The army and the gendarmerie would be instructed by Italians. In exchange, Rome 1) would help the Albanian government reach an agreement with Vatican for the Catholic schools. 2) It declared a ten year moratorium on SVEA's loan obligation and 3) a new loan of 30-40 million gold francs for the agriculture development instead of 100 million credits in unacceptable conditions for King Zogu I. Finally, the Italian government pledged to use the same commercial exchange principles for the Albanian products as with the other European countries. These proposals of Baron Aloisi were rejected by King Zogu I, who considered them dangerous for the loss of the political independence (Fischer, 2004b, pp. 237-238).

Despite the refusal, Italy had penetrated deeper into the domestic policy of Albania. The Italian agents distributed money to develop the propaganda aimed at intensifying the activity of anti-government groups, especially the communists (Selmani, 2008, pp. 242-243). They were indirectly involved in the organizing of Fier uprising, in 1935, though they asked the Albanian feudal aristocrats associated with fascist Italy to withdraw before its outbreak. Perhaps the reason of their withdrawal was the lack of the proper preparation of the uprising, so the disbelief in victory, or not the adequate time for their interests because Rome was engaged in the Abyssinian war (AlH, A.V.42, pp. 11-12).

However, the Italian government had improved the relations with Yugoslavia regarding its political position in Albania. The Foreign Minister of Italy, Galeazzo Ciano, said this information personally to King Zogu I during his visit in Tirana, in April 1937 (AlH, A.V.16, p. 31). A year later, Count Ciano participated in his wedding ceremony with the Hungarian Countess Geraldine Apponyi. He took the opportunity to create a complete idea about the right time and the practical techniques for implementation of Albania's military occupation and then made a detailed report to B. Mussolini 
(AlH, A.V.60, p. 30). Referring to the political action, Count Ciano proposed three alternatives: 1) increasing the political control by strengthening the economic ties; 2) the partition of Albanian territories between Italy, Yugoslavia and Greece, which was a radical choice unacceptable for Albanians who were ready to defend at all costs the independence of Albania; 3 ) the plan of personal union between Albania and Italy through plebiscite, a procedure like that of Anschluss (AlH, A.V.42, p. 58).

In order to facilitate the Italian action to realize any of the above projects, Count Ciano suggested: 1) the withdrawal of Albania from the League of Nations based on the bilateral agreements for a common foreign policy; 2) the prohibition of strengthening the Albanian army. According to the officers of the Italian diplomatic mission, headed by Colonel Bombali, the increase of military's dynamics needed its numerical reduction and the creation of new training centers equipped with automatic weapons. This movement would alarm Yugoslavia and enforce its eventual resistance against Italy. As a result, it was necessary to significantly increase the number of Italian officers in service of the Albanian army with the specific mission to create the annexation groups. 3) Italy's intention was reaching new concession agreements with the Albanian government. Thus, in the near future, an increased number of Italian residents and Albanians would work for the Italian companies. 4) Rome aimed at providing the support of well-known people for the union with Italy through partnership, promises and corruption. While the consent of the lower classes would be guaranteed by investing in hospitals, day care centers, sports organizations etc. (AlH, A.V.38, pp. 13-14).

The Italian government intended to overcome the backwardness and the poverty of the Albanian society. It had decided to spend 6 billion lira on infrastructure, public works and the economic development in general. Italy would not interfere in the domestic and foreign affairs of Albania that was an independent country. It wanted just a friendly state on the other side of the Adriatic Sea coast. Rome sought to guarantee that Albania would not become a tool in the hands of its enemies and to accept an Italian prince from the House of Savoy as King of Albania (Vllamasi, 2000, p. 474).

For that reason, the Italian government strengthened the political and economic relations with Belgrade. On June 18, 1938, during the meeting with Count Ciano in Venetic, the Prime Minister of Yugoslavia, M. Stojadinovic, declared that he would not sign the pact of friendship proposed by the government of Tirana. According to him, the Albanian question was important when the relations with Italy were not good. On the other side, the Italian Foreign Minister, Galeazzo Ciano, in his visit in Belgrade, on January 18-23, 1939, expressed his concern about the difficult situation in Albania and the hatred among people against King Zogu I. He considered the Albanian problem a common issue to both countries. Meanwhile, the chief of the Yugoslav executive, Stojadinovic, claimed that King Zogu I was very capable, if well paid, to help France and Britain in a moment of crisis for Italy. Therefore, he introduced two solutions: 1) the replacement of the Albanian monarch with a more worthy person, but he was not able to propose a name or, 2) the partition of Albania between Italy and Yugoslavia, in order to discuss the issue later because of the lack of details. Stojadinovic said that he didn't want to pursue mediated negotiations by legation rather than their personal agents and trustees, who were appointed respectively, the Minister of Italy, Afuso, and his brother, Dragomir (AlH, A.V.38, pp. 1518).

Furthermore, Count Ciano listed the advantages of Yugoslavia, such as: 1) an agreement to demilitarize the Albanian border; 2) an Italian-Yugoslavian military alliance for the protection of Yugoslavia from Germany because Italy would become a Balkan state, too; 3) some significant modifications of the northern borders of Albania; 4) the elimination of the Albanian nationalist center that encouraged continuously agitations in Kosovo and, 5) the promise of Italy to support the Yugoslavian occupation of Thessaloniki. The Italian Foreign Minister negotiated the rectification of the borders in the North, not the division of the Albanian territories to the benefit of Yugoslavia (AlH, A.V.38, p. 18). This fact was accepted by Prince Pavel with the statement that, within the borders of Yugoslavia had so many Albanians who caused troubles that he didn't want to outnumber them (Vickers, 1995, p. 170). The discussions led to the definite solution of the problem. Thus, there were no difficulties in boundary delimitation. At first, Count Ciano believed that Yugoslavia had not exaggerated pretensions and, secondly, Italy was not interested in possessing 1000 square kilometers more or less on the Albanian territories rather than providing a geostrategic position in the Balkans (AlH, A.V.38, p. 19).

The growing tensions in Europe because of the German invasion of Czechoslovakia forced Italy to take the necessary military measures along the Eastern Adriatic coast ("The Italian interests ..., 1939, p. 1). The aim to put Albania under the Italian protectorate made Count Ciano and Leonardo Vitteti, General Director of the Political Office in the Ministry of Foreign Affairs, prepare a draft-proposal which was sent to King Zogu I by De Ferraris on March 25, 1939. Its content was as follows: Article 1: Italy and Albania would join an alliance with the purpose of guaranteeing the safety by all means and the mutual protection against any attack. Article 2: Rome ensured the friendship between the two countries even in case of a threat to the sovereignty and the territorial integrity of Albania. Article 3: Though the Albanian 
government was in charge of preservation of the public order, Italy was ready to take measures if necessary. Article 4: In order to meet the respective obligations of the alliance, Albania would allow the Italian government to use its ports, airfields and road traffic. Article 5: The permanent diplomatic missions of Italy in Albania and vice versa would be known as embassies. Article 6: Italy offered its technical and financial assistance for the organization of the Albanian state. Every ministry should have an Italian official as General Secretary who exercised the duties of subordinates Albanian Minister. Article 7: Through customs and monetary agreements, Italy would ensure an exchange regime between the two countries similar to the domestic market. Article 8: The Albanian citizens' resident in Italy and vice versa would have all the civil and political rights as native citizens of both countries (Jacomoni, 2005, p. 96). The above agreement was a menace to the independence of Albania, as a result King Zogu I refused to sign it.

Under such circumstances, Count Ciano, completely unprepared to intervene militarily aiming the capitulation of Albania, made a new more moderate proposal on March 31, 1939. As reported by the Italian minister in Albania, Francesco Jacomoni, if the conditions were accepted, G. Ciano would come to solemnly sign the agreement accompanied by aircraft squadrons, otherwise riots would break out (Fischer, 2004a, p. 46). King Zogu I answered that he would continue to respect the terms of the Treaty of the Defensive Alliance with Italy, insisting to oppose each unjust proposal. At the same time, he warned the Great Powers about the danger that threatened the country, but faced the Western apathy. The British government believed the Anglo-Italian agreement of 1938 envisaged maintaining the status quo of the nations in the Mediterranean region (AlH, A.V.10, p. 21). The Prime Minister, A. Chamberlain, himself declared that Britain had no direct interest in Albania, but he asked B. Mussolini to maintain the world peace (AlH, A.V.60, p. 34).

In this situation, King Zogu I appointed a commission headed by Koço Kota to write the counterproposals of the Albanian government, on April 5, 1939, as: 1) to complete a military convention which determined the conditions of the Italian army dislocation allowance; 2 ) the Italians resident in Albania over five years would be called Albanian citizens and they have the right to settle in the cities and establish agricultural societies in the villages; 3 ) a custom fee of $2 \%$ on importing goods could be practiced in both countries; 4) only Italian technicians were allowed to give assistance to the Albanian state institutions. These counterproposals and the request to extend the deadline of the ultimatum were presented to the Italian Minister in Tirana, Francesco Jacomoni.

But, the Italian diplomacy didn't take into consideration the requests of the Albanian government and on April 6 , 1939, the first planes threw leaflets calling the Albanians not to organize a resistance. A day later, the fascist troops commanded by General A. Guzzoni landed in the main ports, such as: Durazzo, Valona, Shengjin and Saranda. In order to avoid the occupation of the country, King Zogu I made the last effort to negotiate with the Italian General that failed unfortunately. Thus, the fascist Italy began the invasion of Albania, violating its sovereignty and the territorial integrity (AlH, A.V.16, pp. 36-37).

\section{Conclusions}

The geostrategic interests of Italy to put control on the Adriatic Sea determined its foreign policy in the Balkans and Albania particularly. Rome supported the new system of governing, the monarchical one, aimed at strengthening the bilateral relations. Its intention was to use the Albanian territory as a port for further deportation towards East.

At first, Italy benefited from the difficult economic situation of the Albanian government, due to the backwardness and the consequences of the Great Depression, to increase its influence offering loans to King Zogu I. Many agreements were signed in order to manage the development of trade, industry and agriculture, the construction of public works, the cancellation of loans' obligations etc. Also, the Italian companies won concessions to exploit the natural resources and they used its market to sell the industrial products. However, despite the considerable benefits of the neighbor on the other side of the Adriatic, the investment of the foreign capital helped the development of the Albanian economy.

Secondly, the Italian government intended to establish its protectorate over Albania. It was disappointed by the non-renewal of the Friendship and Security Pact, in November 1931, and asked the Albanian monarchy to pay SVEA loan and create a customs union. These requests were refused by King Zogu I, because they threatened the sovereignty and the political independence of Albania. In addition, Italy put under pressure the neighboring countries not to invite Albania sign the Balkan Pact (1934), which favored even their interests concerning a weak and not stabilized Albanian state.

Moreover, the Italian political influence was increased through youth education, the presence of its specialists in the state administration, the control on the army etc. In a broader sense, Rome received the consent of the Yugoslavian Chief of Executive, Stojadinovic, to exert its authority over Albania. Count Ciano sent various ultimatums to the 
government of Tirana with the clear purpose to turn Albania simply into an Italian colony. But, King Zogu I rejected them and informed the international factor of the Italian threat. Thus, the British Prime Minister, A. Chamberlain, asked B. Mussolini to maintain the status quo in the Mediterranean, in order to keep peace and stability in Europe. In the contrary, the fascist Italy invaded Albania on April 7, 1939.

\section{References}

Albanian's State Archive (AQSH), F. 263, V. 1933, D. 25, pp.13-14 (The reports and the correspondence with the Ministry of Foreign Affairs of Italy, concerning the crisis of Zogu's cabinet due to the economic collapse and the country's poverty etc.)

The Archive of Institute of History (AIH), A.V.60 (The foreign relations of Albania during 1924-1939, Arben Puto)

AlH, A.V.16 (Busch - Zautner, Albania under the regime of Zogu)

AlH, A.V.42 (The domestic policy of Albanian Monarchy, Alqi Kristo)

AlH, A.V.43 (The economic and the financial policy of Ahmet Zogu)

AlH, A.V.85 (Th. Laskaris, "The diplomatic history of contemporary Europe 1914-1939", Thessaloniki, 1954)

AlH, A.V.38 (The secret archives of Count Ciano, 1936-1942)

AlH, A.V.10 (The Italian occupation of Albania)

"Albanian properties of kerosene were evaluated in the Italian Senate. The balance of the past and a look at the future", Gazeta Shqiptare, XVIIth year, no.127, Bari, Wednesday, May 30th 1939 , p. 1

Attoma, N. L. "The value and the importance of the economic and financial agreements between Italy and Albania", Gazeta Shqiptare, Bari, $X^{\text {th }}$ year, no.71, Sunday, March 22, 1936, p. 1

Bakalli, E. (2001). "The Balkan Pact and Albania", Historical Studies, no. 1-2, 2001, LV year, Tirana, pp. 67-70

Canco, D. "The Italian-Yugoslavian relations and Albania", Albania Nouâ, X't year, no. 375, Kostanca, Sunday, June 23, 1929, p. 2

Editorial notes. "The Balkan Conference", Dielli, vol. XXII 22 nd year, no. 5205, Boston Mass., Tuesday, October 14, 1930, p. 2

Fischer, B. J. (2004a). Albania at war, 1939-1945. Tirana: Çabej

Fischer, B. J. (2004b). King Zog and the struggle for stability in Albania. Tirana: Çabej

Frashëri, M. (2005). Memories (1913-1933). Tirana: OMSCA-1

Gogo, G. (1938). The monarchy of Zogu I and its people. Tirana: "Kristo Luarasi"

Grant, H. H. (2002). King Zogu I, as I have known. Tirana: The International Institute of Monarchical Studies and of the Albanian Centre of the American and the British Studies "Virginia"

Jacomoni, F. (2005). La Politica dell'Italia in Albania. Tirana: Ora

Kareco, T. (2010). Scandal with the book: "The History of the Albanian People, vol. 3". Tirana: Klean

Laporte, H. "Albania and its King", Arbëria, Tirana, 2nd year, no. 422, Sunday, November 22, 1936, p. 3

Meta, B. (2011). "The policies of the Albanian State towards the minorities during the monarchy", The Albanian Monarchy 1928-1939.

The Centre of Albanological Studies. Institute of History. Tirana: Toena, p. 52

Selmani, H. (2008). From the activity of Zogu I, King of Albanians. Tirana: "Kristalina-KH"

Smirnova, N. (2004). The history of Albania during the $20^{\text {th }}$ century. Tirana: Ideart

Swire, J. (2005). Albania. The rise of a Kingdom. Tirana: Dituria

The Academy of Science of Albania (2007). The History of the Albanian People, vol. 3. Tirana: Toena

"The Italian interests and its safety in the Adriatic Sea", Gazeta Shqiptare, XVIlth year, no.83, Bari, Saturday, April 8, 1939, p. 1

Vickers, M. (1995). Albanians in the international optics. Athens: Georgo K. Geru

Vllamasi, S. (2000). Political confrontations in Albania: 1897-1942. Tirana: Neraida

"What is the base of the Italian-Albanian friendship? The support of the ally for the consolidation of the Albanian state", Ora, $2^{\text {nd }}$ year, no. 476, Tirana, Thursday, November 19, 1931, p. 1 